\title{
Low Molecular Weight Dextran Infusions in Systemic Sclerosis with Raynaud's Phenomenon: A Report of Nine Cases
}

\author{
PETER LANE,* B.M., B.CH., M.R.C.P.ED.
}

British Medical fournal, 1970, 4, 657-659

Cummary: Two litres of low molecular weight dextran in normal saline were given intravenously over 48 hours to 10 patients with systemic sclerosis and Raynaud's phenomenon. The finger temperatures of nine were recorded under standardized conditions. One patient had lowered temperatures of the fingers, two had a rise in temperature, and six had no change. There were no side effects of the treatment. None of the 10 patients showed any clinical improvement.

\section{Introduction}

Low molecular weight dextrans (average molecular weight of 40,000 ) are said to reduce red cell aggregation within the vessels, lower blood viscosity, and thus increase capillary flow. This is quite apart from their haemodilution effect due to an increase in plasma volume. They have been called "de-sludging agents" (Gelin and Zederfeldt, 1960).

Systemic sclerosis is an intractable condition for which there is no specific treatment, and low molecular weight dextrans have been given to patients with this disease when associated with Raynaud's phenomenon. Holti (1965) claimed that 10 out of 12 cases "markedly benefited from the treatment for long periods with a readily demonstrable increase in blood flow, healing of ulcerated finger tips and disappearance of ischaemic pain." It was decided to try to treat a similar series of patients in Leeds.

\section{Patients and Methods}

Patients.-Ten patients started in the trial but the readings of only nine are included in the objective assessment (see below). Five were women aged 32 to 47 (mean 39) years and four were men aged 23 to 58 (mean 45 ) years. The duration of Raynaud's phenomenon varied from 2 to 27 years, the mean being 11 years (see Table I). All patients were suffering from unequivocal systemic sclerosis with Raynaud's phenomenon. In view of the reports of acute uraemia following use of low molecular weight dextran infusions (Mailloux et al., 1967), it was considered essential that all patients receiving these should have urine normal to routine investigation, normal blood ureas, and a creatinine clearance of over $50 \mathrm{ml} . / \mathrm{min}$.

\section{Methods}

The trial period was January to November 1967. Patients were admitted to hospital to become acclimatized to the ward temperature. Two days later each patient was taken to a specially heated room with a constant temperature of $26^{\circ} \mathrm{C}$. This "hot-room" was constructed for the medical unit and was free from draughts. Patients sat in comfort in this room for two hours, after which the first temperature readings were taken.

The technique described by Holti (1965) was followed. This aims at reducing any element of vascular spasm and thus standardizing the procedure as much as possible. After sitting in the hot room for two hours the patients placed both legs in a bucket of water maintained by thermostatic control at a constant temperature of $44^{\circ} \mathrm{C}$. for 30 minutes. The digital temperatures were then retaken with the feet still

* Formerly Tutor and Senior Registrar, Department of Dermatology, General Infirmary at Leeds. At present Honorary Lecturer in Photobiology, Department of Medicine, University of Natal, Durban; Senior Dermatologist, Addington Hospital, Durban; and Consultan Dermatologist, King George V Hospital, Durban. Address for reprints: 35 Syfret House, Gardiner Street, Durban. immersed in hot water. The oral temperatures were $37.8^{\circ} \mathrm{C}$. In this way it was hoped that maximal vasodilatation was obtained.

The machine used for recording the temperatures was the Electric Universal Thermometer, type TE3, made by Ellab Instruments of Copenhagen, which operates on the thermocouple principle. The $\mathrm{H} 2$ skin applicator was used. For recording the temperatures the skin applicator was placed on the flexor aspect of the fingers, midway between the tip of the finger and the distal interphalangeal crease. Gentle pressure was exerted on the skin applicator and an average of three readings taken for each finger on each occasion. The three readings were usually the same, but always within $0.2^{\circ} \mathrm{C}$. of each other. These measurements were made before giving low molecular weight dextran and then three days, one week, and four weeks after the transfusion. Three patients were followed for six months. Standard transfusion apparatus was used, and the $10 \%$ low molecular dextran (Lomodex) was given in normal saline at the rate of 2 litres in 48 hours. One patient (Case 10) was unable to tolerate the temperature of the water in the bucket, so digital temperatures were taken in the "hot-room" without immersion of the legs in hot water. His readings are not included in the trial.

Controls.-There were five healthy control subjects-three men, mean age 36 years, and two women aged 21 and 18 . These healthy controls were not admitted to the ward, but all worked in the warm environment of the hospital. Apart from this the conditions of testing were identical. The readings were taken three times at weekly intervals. Four of the systemic sclerosis patients (Cases 2,3,5, and 8) had several skin temperatures taken before transfusion of low molecular weight dextran. The two men (Cases 2 and 3 ) had had bilateral sympathectomies over eight years previously.

\section{Results}

The mean range of the temperatures of the fingers of the healthy controls after 15 readings when the feet were not immersed was $2.5 \mathrm{C}$. When the feet were immersed at $44^{\circ} \mathrm{C}$. the mean range was only $0.4^{\circ} \mathrm{C}$. The mean range in the temperatures of the fingers of the systemic sclerosis patients after 10 readings when the feet were not immersed was $1.7^{\circ} \mathrm{C}$. When the feet were immersed at $44^{\circ} \mathrm{C}$. the mean range was $0.6^{\circ} \mathrm{C}$. These results confirm that there is much less temperature variation, both in healthy controls and in systemic sclerosis patients, when readings are compared after immersion of the feet in hot water. Readings taken when the feet were not immersed showed a wide range of variation up to $4^{\circ} \mathrm{C}$.

The finger temperatures when the feet were immersed in hot water three days, one week and four weeks after the low molecular weight dextran transfusions were recorded (Table II). It is difficult to decide what constitutes a significant change in temperature. From the studies with healthy people and systemic scierosis patients one might perhaps suggest that $1^{\circ} \mathrm{C}$. is significant-this represents about a $3 \%$ change. If one uses this as the criterion then the following results are obtained (Table II): raised temperatures in Cases 1 and 8, no change in six cases and lower temperatures in Case 6. None of the patients had any clinical benefit whatever. One patient (Case 5) thought her hands were softer than before treatment; this was purely subjective. Pulmonary diffusion studies were made in five 
TABLE I.-Patients with Systemic Sclerosis

\begin{tabular}{|c|c|c|c|c|c|c|c|c|c|c|}
\hline \multirow{2}{*}{$\begin{array}{l}\text { Case } \\
\text { No. }\end{array}$} & \multirow{2}{*}{ Sex } & \multirow{2}{*}{ Age } & \multirow{2}{*}{$\begin{array}{l}\text { Duration of } \\
\text { Raynaud's } \\
\text { Phenomenon } \\
\text { (years) }\end{array}$} & \multirow{2}{*}{$\begin{array}{l}\text { Duration of } \\
\text { Cutaneous } \\
\text { Changes in } \\
\text { Years. Hands } \\
\text { or Face }\end{array}$} & \multirow{2}{*}{$\begin{array}{l}\text { Sympathectomy } \\
\text { Right or Left }\end{array}$} & \multicolumn{3}{|c|}{ Pulmonary Diffusion (\%) } & \multirow{2}{*}{$\begin{array}{c}\text { After } \\
\text { Transfusion. } \\
\text { Subiective } \\
\text { Symptoms }\end{array}$} & \multirow{2}{*}{ Comments } \\
\hline & & & & & & Before & After & Change & & \\
\hline 1 & M. & 51 & 6 & 4 & $\mathrm{Nil}$ & \multicolumn{3}{|c|}{$\begin{array}{l}\text { Not done. Barium } \\
\text { swallow aperistaltic } \\
\text { before and after } \\
\text { transfusion }\end{array}$} & Nil & $\begin{array}{l}\text { No clinical improvement. Unexplained rise in } \\
\text { skin temp. maintained. Had to give up work } \\
\text { as bricklayer }\end{array}$ \\
\hline 2 & M. & 48 & 13 & 12 & R. and L. & 47 & 43 & Nil & Nil & $\begin{array}{l}\text { No clinical improvement. Calcinosis cutis. } \\
\text { Pulmonary changes. Had been on } \\
\text { vasodilators }\end{array}$ \\
\hline 3 & M. & 23 & 13 & 10 & R. and $\mathrm{L}$. & 138 & 142 & $\mathrm{Nil}$ & Nil & No clinical improvement. Calcinosis cutis \\
\hline 4 & F. & 36 & 12 & 7 & $\mathrm{Nil}^{-10}$ & 82 & 83 & Nil & Nil & $\begin{array}{l}\text { No clinical improvement. Siögren's syndrome. } \\
\text { Had p-aminobenzoate (Potaba) 1961. Sodium } \\
\text { calciumedetate (Versene). 1961 }\end{array}$ \\
\hline 5 & F. & 36 & 2 & 1 & Nil & 113 & 116 & Nil & $\begin{array}{l}\text { Thought } \\
\text { hands } \\
\text { were softer }\end{array}$ & $\begin{array}{l}\text { No clinical improvement. Early Sjögren's } \\
\text { syndrome }\end{array}$ \\
\hline 6 & F. & 47 & 27 & 6 & $\begin{array}{l}\text { R. and } L . \\
1953\end{array}$ & \multicolumn{3}{|c|}{ Not done } & Nil & No clinical improvement \\
\hline 7 & F. & 32 & 17 & 15 & $\begin{array}{l}\text { R. and } L . \\
1960\end{array}$ & \multicolumn{3}{|c|}{ Not done } & $\begin{array}{l}\text { R. hand } \\
\text { warmer } \\
\text { than } \\
\text { L. hand }\end{array}$ & No clinical improvement \\
\hline 8 & F. & 47 & $\begin{array}{l}\text { (Cold hands } \\
\text { all life) }\end{array}$ & 5 & Nil & 83 & 80 & Nil & $\mathrm{Nil}$ & $\begin{array}{l}\text { No clinical improvement. Had phenoxyben- } \\
\text { zamine } 10 \mathrm{mg} \text {. b.d. } 1969\end{array}$ \\
\hline 9 & M. & 58 & 5 & 3 & Nil & 77 & 81 & Nil & Nil & $\begin{array}{l}\text { No clinical improvement. } 1965 \mathrm{~L} \text {. ring finger } \\
\text { amputated. Has had gangrene of } R \text {. index } \\
\text { finger for } 4 \text { months }\end{array}$ \\
\hline 10 & M. & 36 & 5 & 5 & R. 1963 & 82 & Not & done & $\mathrm{Nil}$ & $\begin{array}{l}\text { No clinical improvement. No temperature } \\
\text { readings taken with legs immersed in hot } \\
\text { water }\end{array}$ \\
\hline
\end{tabular}

TABLE II.-Finger Temperatures of 9 Cases of Systemic Sclerosis after 2 Litres of $10 \%$ Low Molecular Weight Dextran in Normal Saline Intravenously over 48 Hours.

\begin{tabular}{|c|c|c|c|c|c|c|c|c|}
\hline \multicolumn{8}{|c|}{$\begin{array}{c}\text { Average Change in Temperature in Both Hands with Readings Taken } \\
3 \text { Days, } 1 \text { Week, and } 4 \text { Weeks after receiving Low Molecular Weight } \\
\text { Dextran }\end{array}$} & $\begin{array}{c}\text { Case } \\
\text { Nos. } \\
6\end{array}$ \\
\hline 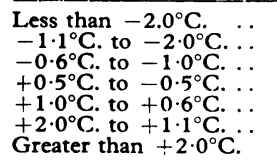 & $\begin{array}{l}\cdots \\
\cdots \\
\cdots \\
\cdots \\
\cdots\end{array}$ & $\begin{array}{l}\cdots \\
\cdots \\
\cdots \\
\cdots \\
\cdots \\
\cdots\end{array}$ & $\begin{array}{l}\cdots \\
\cdots\end{array}$ & $\begin{array}{l}\cdots \\
\cdots \\
\cdots \\
\cdots \\
\cdots \\
\cdots\end{array}$ & $\begin{array}{l}\ldots \\
\cdots \\
\cdots \\
\cdots \\
\cdots\end{array}$ & $\ldots$ & $\begin{array}{l}\cdots \\
\cdots \\
\cdots \\
\cdots \\
\cdots \\
\cdots\end{array}$ & $\begin{array}{c}6 \\
\text { Nil } \\
2,9 \\
3,5,7 \\
4 \\
8 \\
1\end{array}$ \\
\hline
\end{tabular}

patients before and after treatment and no change was noted. One patient (Case 1) had a barium swallow before and after treatment and the aperistalsis showed no change. The patient (Case 10) who could not tolerate the hot water in which to immerse his feet also had no clinical improvement.

No patient had any side effects from the administration of low molecular weight dextran. There were no changes in the urine or blood ureas of the patients before and after treatment, or in the creatinine clearance tests in the six patients tested before and after treatment (see Table III).

The results therefore failed to show any practical benefit to the patients following treatment with low molecular weight dextran.

TABLE III.-Readings before and after Giving 2 Litres of $10 \%$ Low Molecular Weight Dextran in Normal Saline Intravenously over 48 Hours.

\begin{tabular}{|c|c|c|c|c|c|c|c|c|}
\hline & \multirow{2}{*}{$\begin{array}{l}\text { Case } \\
\text { No. }\end{array}$} & & \multicolumn{2}{|c|}{$\begin{array}{c}\text { Urine } \\
\text { Routine Testing }\end{array}$} & \multicolumn{2}{|c|}{$\begin{array}{l}\text { Blood Urea } \\
\text { (mg./100 ml.) }\end{array}$} & \multicolumn{2}{|c|}{$\begin{array}{l}\text { Creatinine Clearance } \\
\text { Test (ml./min.) }\end{array}$} \\
\hline & & & Before & After & Before & After & Before & After \\
\hline $\begin{array}{l}1 \ldots \\
2 \ldots \\
3 \ldots \\
4 \ldots \\
5 \ldots \\
6 \ldots \\
7 \ldots \\
8 \ldots \\
9 \% \\
10 \ldots\end{array}$ & $\begin{array}{l}\ldots \\
\cdots \\
\cdots \\
\cdots \\
\cdots \\
\cdots \\
\cdots\end{array}$ & $\begin{array}{l}\cdots \\
\therefore \\
\therefore \\
\therefore \\
\therefore \\
\cdots \\
\cdots\end{array}$ & $\begin{array}{l}\text { N.A.D. } \\
\text { N.A.D. } \\
\text { N.A.D. } \\
\text { N.A.D. } \\
\text { N.A.D. } \\
\text { N.A.D. } \\
\text { N.A.D. } \\
\text { N.A.D. } \\
\text { N.A.D. } \\
\text { N.A.D. }\end{array}$ & $\begin{array}{l}\text { N.A.D. } \\
\text { N.A.D. } \\
\text { N.A.D. } \\
\text { N.A.D. } \\
\text { N.A.D. } \\
\text { N.A.D. } \\
\text { N.A.D. } \\
\text { N.A.D. } \\
\text { N.A.D. } \\
\text { N.A.D. }\end{array}$ & $\begin{array}{l}27 \\
40 \\
25 \\
31 \\
38 \\
36 \\
28 \\
22 \\
31 \\
33\end{array}$ & $\begin{array}{l}34 \\
31 \\
29 \\
25 \\
35 \\
34 \\
28 \\
19 \\
30 \\
31\end{array}$ & $\begin{array}{r}91 \\
73 \\
94 \\
147 \\
56 \\
76 \\
94 \\
57 \\
72 \\
94\end{array}$ & $\begin{array}{c}\text { Not done } \\
\text { Not done } \\
84 \\
\text { Not done } \\
55 \\
91 \\
93 \\
74 \\
66 \\
\text { Not done }\end{array}$ \\
\hline
\end{tabular}

\section{Discussion}

Holti's (1965) method of standardizing the conditions for taking the temperatures was found to be satisfactory. It is suggested, however, that it may not be necessary to admit patients to the ward or even a "hot-room" to obtain such standardization. Three of the healthy controls were also tested in the warm outpatient department behind screens to exclude draughts. Their feet were immersed in hot water as before and their readings were within $0.5^{\circ} \mathrm{C}$. of those recorded in the "hot-room" on previous occasions. If this could be confirmed on more patients it would be of great practical importance in investigating patients with peripheral vascular disease.

No reason can be given for the sustained rise of about $5^{\circ} \mathrm{C}$. in the temperatures of the fingers of Case 1 . Being the first patient in the trial his readings were taken many times before the transfusion, and his post-transfusion readings were made over a period of six months. The rise in his temperature has been sustained, but he has had no clinical improvement and is quite unable to follow his occupation as a bricklayer.

Evarts (1967) reviewed the properties of low molecular weight dextran extensively. While its therapeutic benefit in acute ischaemia seems undecided, the possible benefit to patients with chronic peripheral vascular diseases appears to be even more uncertain (Bergan et al., 1965). The initial report of Powley (1963) suggesting therapeutic benefit from low molecular weight dextran was based on only five cases, four of which suffered from acute ischaemia. The report of Bienenstock and Harding (1964) was based on only four cases. Perhaps more weight should be given to Singer's (1965) series of 16 patients at the Mount Sinai Hospital, New York, where objective measurements were included and only two patients showed benefit. One of these had frost-bite, and the other had only a few days' improvement in her chronic ischaemia before surgery became necessary.

Mailloux et al. (1967) stated that 14 cases of acute renal failure had been reported after the infusion of low molecular weight dextran. Three of these cases were their own patients, 
all of whom died. Morgan et al. (1966) also reported three cases of acute renal failure, of which one was fatal, following prolonged low molecular weight dextran therapy. This hazard is of particular importance when the possible therapeutic effect remains uncertain. No complications were experienced by the 10 patients of this series who received 2 litres of low molecular weight dextran over 48 hours.

Kirk and Dixon (1969) reviewed six patients with systemic sclerosis who received low molecular weight dextran. As a result of their investigation they state: "Objective evaluation suggests that no alteration in the course of the disease of practical value is likely to be achieved by dextran infusions." The results of this series are in accord with this but do not confirm, however, their statement that "the peripheral circulation is improved in most patients." They do not give details of their temperature measurements or the objective measurement they consider a significant rise.

Final conclusions cannot be drawn from this series of 10 patients, of whom only nine had objective measurements. Also each patient in this series had only one infusion of low molecular weight dextran. A much larger series with controls and objective measurements would be of great value.
All the patients in the trial were under the care of Dr. N. R. Rowell, department of dermatology, General Infirmarył Leeds. Dr. J. B. Stoker undertook the pulmonary diffusion studies and used the single-breath method of Ogilvie et al. (1957). Miss Dingwall Fordyce, of the department of public health, University of Aberdeen, gave valuable advice.

\section{REFERENCES}

Bergan, J. J., Trippel, O. H., Kaupp, H. A., Kukral, J. C., and Nowlin, W. F. (1965). Archives of Surgery, 91, 338 .

Bienenstock, J., and Harding, E. X. T. (1964). Lancet, 1, 524.

Evarts, C. M. (1967). Medical' Clinics of North America, 51, 1285.

Gelin, L.-E., and Zederfeldt, B. (1960). Acta Chirurgica Scandinavica, 119,168 .

Holti, G. (1965). British Fournal of Dermatology, 77, 560.

Kirk, J. A., and Dixon, A. St. J. (1969). Annals of the Rheumatic Diseases, 28, 49.

Mailloux, L., et al. (1967). New England Fournal of Medicine, 277,

Morgan, T. O., Little, J. M., and Evans, W. A. (1966). British Medical fournal, 2, 737.

Ogilvie, C. M., Forster, R. E., Blakemore, W. S., and Morton, J. W. (1957). Fournal of Clinical Investigation, 36, 1.

Powley, P. H. (1963). Lancet, 1, 1189.

Singer, A. (1965). Lancet, 2, 1050.
Delayed myelopathy is a rare complication of electrical burns. Panse (1930), Hyslop (1949), Silversides (1964), and Jackson et al. (1964) have all described such cases. In view of its rarity the following case is reported.

\section{CASE REPORT}

On 2 June 1969 a previously-fit 23-year-old unemployed labourer attempted to remove an electrical cable by cutting through it with a hacksaw held in his left hand, unaware that the cable carried 33,000 volts. He was conscious of a flash but of nothing further until he awoke in hospital. At this time he was able to move all his limbs and ta get out of bed without assistance.

On 5 June he was admitted to the burns unit with a superficial burn typical of an electrical flash injury covering $15 \%$ of the body surface. It involved the face, the front of the neck and chest, and part of the right thigh. There were localized patches of full-thickness destruction suggestive of direct electrical contact on both hands, the right leg, and the epigastrium. General examination revealed no other abnormalities.

On the eighth day he developed partial anaesthesia of the left thumb and index finger which could not be explained by direct burn injury of the peripheral nerves. At 12 days a spastic paresis occurred in both lower limbs, with extensor plantar responses and sensory impairment of all modalities. By the 14th day the weakness had spread to his arms.

At 21 days his condition was at its worst, with almost total paralysis and sensory loss in all limbs. Tendon reflexes were pathologically increased in the legs and absent in the arms, and there was pronounced wasting of the interossei. Bowel, bladder, and respiratory control were normal throughout. Regular examination of his fundi showed no abnormality.

He began to improve, sensation returning before motor power. At 35 days he was able to raise his legs from the bed and at 56 days could stand unsupported. His burns were treated conventionally by split-skin grafts. When they had healed he was admitted to the Liverpool Regional Paraplegic Centre on 13 August, 72 days after the injury. At this stage he had pronounced wasting and almost total paralysis of the thenar and interosseus muscles (see Fig.); the legs remained weak. The tendon reflexes were pathologically increased in all four limbs. The only remaining sensory impairment was in a glove distribution. With intensive physiotherapy improvement continued, and after four months (120 days) he could dress himself unaided. At this time he complained of blurred vision and was found to have developed bilateral cataracts. By the time of his discharge one month later (160 days) he could walk with the aid of two sticks and was independent, but the physical signs were unchanged.

Investigations.-Haemoglobin, W.B.C., blood urea, and E.S.R. were normal. Radiographs of the cervical, dorsal, and lumbar spine taken at the onset of symptoms and repeated later showed nothing abnormal. Radiographs of the hands taken late in the recovery period showed regional osteoporosis. Lumbar puncture performed soon after the onset and repeated in the recovery phase showed a free rise and fall of pressure, normal protein with no excess globulin, no xanthochromia, and no red blood cells. Lange test in all dilutions and W.R. were negative. E.C.G. showed sinus rhythm with deeply inverted T waves in leads I, II, and aVL and in chest leads V3-5. Findings on electromyography were compatible with a lower motor neurone lesion in the arms and an upper motor neurone lesion in the legs.

\section{Discussion}

Anatomically the picture presented was compatible with a lesion in the cervical cord. Since there was no previous his-

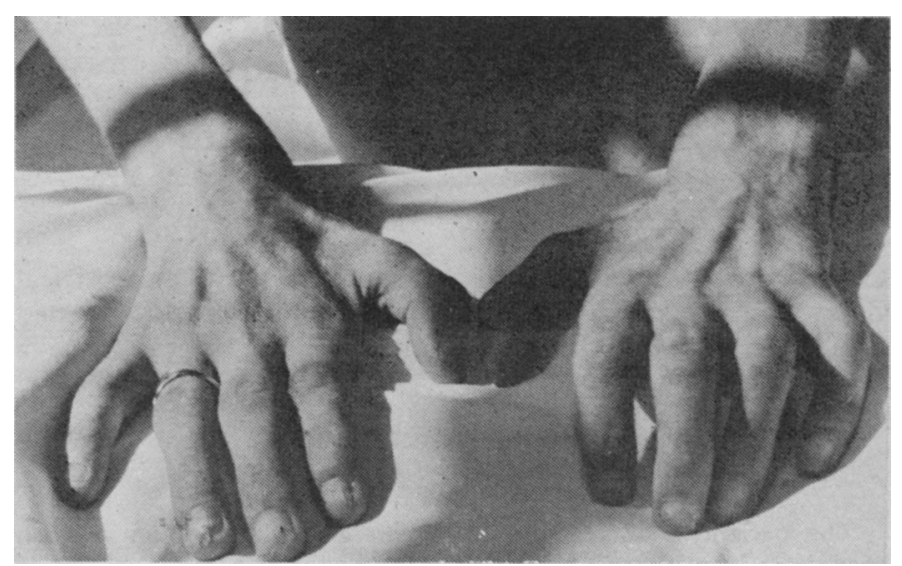

Pronounced wasting of the interossei and thenar muscles some months 